DOI: $10.24193 /$ tras.64E.4

Published First Online: 28/31/2021

\section{A CONTENT ANALYSIS OF PUBLIC POLICY DESIGN AND IMPLEMENTATION IN SLOVENIA: WEIGHING STRATEGIC AND NORMATIVE FACTORS}

\section{Žiga KOTNIK \\ Dalibor STANIMIROVIĆ}

\section{Žiga KOTNIK}

Assistant Professor, PhD, Faculty of Public Administration, University of Ljubljana, Ljubljana, Slovenia

E-mail: ziga.kotnik@fu.uni-lj.si

\section{Dalibor STANIMIROVIĆ}

Assistant Professor, PhD, Faculty of Public Administration, University of Ljubljana, Ljubljana, Slovenia

E-mail: dalibor.stanimirovic@fu.uni-lj.si

\section{Abstract}

Policy processes are complex systems and require an in-depth and comprehensive analysis. Especially, factors that affect public policy design and implementation, as two important stages of the public policy cycle, have not been sufficiently explored. The aim of the paper is to analyze the relationship between two critical factors that influence the design and implementation of public policies in the case of Slovenia, namely strategic factors and normative factors, and offer a basis for comparison with similar countries.

Based on twenty-two structured interviews with prominent public policy experts in Slovenia and content analysis of the responses, the findings reveal that, although strategic factors are identified by the interviewees as the most critical, the role of normative factors is also important and should not be underestimated. For various reasons, in practice, normative factors often turn out to be crucial.

Keywords: regulation, public administration, content analysis, structured interviews. 


\section{Introduction}

Each modern society needs to promote a strategic vision regarding its future development (Hintea, 2008). Traditionally, public administration as such is not associated with managerial approaches or entrepreneurial spirit, but is rather characterized as a rigid, immovable and inert system that follows a relatively conservative and legalistic approach. Due to great social, economic, political and technological challenges, public administration has been forced to start adapting to these pressures (Pollitt and Bouckaert, 2011). Strategic planning has become a primary obligation for public institutions through New Public Management reforms. In this process, which started with strategic planning, the aim is to construct a management culture that will enable public institutions on all levels of government to be governed strategically for efficiency and accountability (Demirkaya, 2015). In the last decades, strategic planning has been criticized for being overly rational and for inhibiting strategic thinking, for focusing too much on the degree of fit between available resources and current opportunities (Hill and Jones, 2011).

Nowadays, public management reforms represent a constant feature of the change efforts undertaken by different government levels in almost all countries in the world. Strategic planning was introduced in the public sector over thirty years ago and has since become a core component in many New Public Management reforms (Johnsen, 2016). While strategic planning has been widely adopted in the Anglo-Saxon setting, the knowledge base and its implementation remain limited, especially in the post-communist countries, for example in Slovenia.

Strategic planning in Slovenia has become important after the democratization during the process of transition to market economy in the early 1990s (Deželan, Maksuti and Ursic, 2014). Despite its post-socialist legacy from the former Yugoslavia (1918-1991), Slovenia, as an EU member since 2004, is today well known for its legalistic administrative culture. This is especially evident in the country's eagerness to follow the OECD guidelines and best practices, which further strengthen the regulatory framework by de facto enabling the executive to rule by governmental decrees and ministerial rules (Kovač and Bileišis, 2017). There has however been little research that closely analyzes how and to what extent the national government in Slovenia has systematically and continually attempted to design and implement public policies.

The design and implementation of public policies, programs, and projects (PPPPs) are determined as well as framed by a variety of factors and players, where each player has its own interests, powers, and resources. Especially, the strategic and normative factors that affect the design and implementation of PPPPs as two important stages of the policy cycle have not been sufficiently explored (Johnsen, 2015). To date, no empirical studies of these policy factors and their effects on PPPPs in Slovenia have analyzed contested issues. By analyzing the strategic planning aspects within the normative framework of the Slovenian public administration, the article will examine the role and significance of strategic and normative factors for the public policy design and implementation. 
The article addresses the above-mentioned gap and reveals the need for a comprehensive analysis concerning the design and implementation of public policies. The relevance of the paper is demonstrated in the multidisciplinarity of the topic, as required by such systemic societal challenges. Until now, studies have been performed without exception in the specific policy area(s), whereby this article offers a comprehensive analysis of the strategic and normative factors for design and implementation of public policy, applicable extensively for all or most policy areas. The aim of the paper is, therefore, to analyze the case of Slovenia, define, analyze and study the relationship between two critical factors that influence the design and implementation of public policies, namely strategic factors and normative factors, and offer a basis for comparison with similar countries.

\section{Literature review}

The literature provides insight into various theories on public policy decision-making, from rationalistic approach (Downs, 1957), in the form of the rational choice theory (pure rational decision-making), bounded rationality (Simon, 1957) and incrementalist approach (Lindblom, 1959) to mix-scanning (Etzioni, 1967). In response to criticisms of existing approaches and as a search for new ones a next generation of theories have emerged, e.g., garbage can theory (Cohen, March and Olsen, 1972), punctuated equilibrium (Baumgartner and Jones, 2010), advocacy coalition theory (Sabatier, 1988) and (good) governance theory (Keping, 2018), among others. Particularly the latter, the good governance theory, is one of the key theories to analyze modern public policy design and implementation processes (Ongaro and van Thiel, 2018). Several major international organizations (the IMF, the OECD, the UN, etc.) concur that strategic vision (strategic factors) and the rule of law (normative factors) represent some of the most important principles of the good governance theory (Kovač and Bileišis, 2017; UN, 2021). Furthermore, a recent study demonstrated that the good governance theory is the most suitable to portray strategic and normative factors in policy decision-making (Kotnik et al., 2020).

The World Bank identifies good governance as a capacity of governments to design, formulate, and implement policies (Weiss, 2000). Good governance means the use of political authority and exercise of control in a society in relation to the management of its resources for social and economic development (OECD, 1995). Good governance also represents a dynamic collaboration between the government and citizens with a focus on establishing a public network for various public policy actors to participate and debate within policy processes. In practice, businesses, government bureaucracy, civil society, and interest groups are usually involved in the process (Keping, 2018). Good governance principles rely above all on rule of law, strategic vision, transparency, effectiveness and efficiency, public participation, responsiveness, equity, consensus orientation, and accountability (Johnston, n.d.). 
The literature defines several public policy factors (Johnsen, 2016; Mencinger et al., 2017; Vintar, Aristovnik and Klun, 2018; Volkery and Ribeiro, 2009), namely: regulation, strategy, organizational structure, financial resources, stakeholders involvement, and ICT, among others. After broadly examining all the above factors and their context in previous research (Mencinger et al., 2017), the analysis below is focused on two constructs, respectively, strategic vision (strategic factors) and the rule of law (normative factors).

Strategic vision (strategic factors), one of the nine essential principles of good governance, represents concrete instruments that steer the actions of individual players and institutions, and may aid all stakeholders to jointly work on international, regional, national or local level and produce synergy effects between them (Council of Europe, 2018). The results of the survey among 22 top-ranked public policy experts in Slovenia (Mencinger et al., 2017) demonstrate that among six key public policy factors, strategic factors were found to be the most influential public policy factors. Similarly, an IFAC study (IFAC, 2004) provides evidence that strategic factors are significant, but not enough within the public policy process to effectively and efficiently carry out a certain policy. In this regard, the European Union adopted several important legal and strategic documents for all major policy areas (EC, 2015). In our research, these documents are considered strategic factors, and are more or less consistently followed at the national level (MJU, 2015). In other words, the strategic factors are defined as the use of a strategic approach, i.e., the existence of general and policy-specific strategies, action plans, and other long-term policy documents, both national/international and EU-related (Kotnik et al., 2020).

The rule of law (normative factors) implies that the law is the supreme principle in public administration and ought to be respected by all government officials and citizens. The immediate goal of the rule of law is the management of social affairs, the regulation of citizens' behavior, and maintenance of the normal order in social life. In this view, the 'rule of law' is an elementary prerequisite of good governance that would not be possible without a firm legal system (Kovač and Bileišis, 2017). The role of the legal factors lies in defining the relevant values and determining responsibilities in pursuing the public interest (Bennett and Howlett, 1992). Therefore, normative factors are defined as the legal/regulatory framework available to enforce PPPPs design (e.g., the legislative process) and implementation (Kotnik et al., 2020). Accordingly, based on the outlined theoretical background and selected constructs from the literature review, this paper focuses on one underlying hypothesis, namely: 'public policymaking in Slovenia is mainly based on following rules rather than on appropriate strategies'. 


\section{Methodology}

\subsection{Research design}

The paper employs an exploratory content analysis research design supported by a broad review of literature and the investigation of numerous sources containing problem-related content. A content analysis method was applied to structured interviews and object-oriented discussions with prominent experts in the field. The research on the role and significance of strategic and normative factors in public policy design and implementation in Slovenia was conducted from February to September 2017. A part of the research method was adapted to the particularities of the research problem and the implications thereof (Kotnik and Kovač, 2018; Yin, 2017). Since this research is largely exploratory in nature, quantitative empirical methods could not yield satisfactory results. Accordingly, a content analysis (a qualitative approach) was considered the most favorable methodological approach to understanding this complex field of research. Structured interviews were used as the main data collection technique during the formative research phase.

\subsection{Sample}

The selection of the potential interviewees was based primarily on their expertise and experience in order to ensure the credibility and validity of their views and recommendations, as well as to facilitate constructive participation in the research (Yin, 2017). A non-random stratified sampling approach was used to ensure a representative sample of experts that satisfy the required conditions. The response rate was approximately 70\%; namely, out of approximately 35 invited experts, 22 responded to the invitation and ultimately participated in the interviews. The 22 interviewees were chosen from 15 key areas (spatial planning policy, labor and social policy, science and research, traffic policy, migration and asylum policy, budgetary policy, environmental protection, consumer protection, administrative law and policy, education (primary, tertiary), tax policy, local self-government, health policy, digital policy, and cultural policy). The participating experts were typically senior officials from different institutions: most of them from ministries (15), as well as from non-governmental organizations (3), inspectorates (2), institutes (1), and agencies (1). Most of the interviewees were directors (of directorates, agencies, and institutes), state secretaries, and former ministers. Representatives of non-governmental organizations were invited to participate in the research as part of efforts to gain the widest possible insight into the public policymaking process, where non-governmental organizations often participate as important agents of various social groups. Quotas of experts in each area, totaling 22 , were determined after reaching saturation point. The experts involved in the interviews currently occupy the top positions at different levels of the administrative-political system. The participants were aged between 39 and 70 years, whereas the ratio between men and women was 12 to 10 (12 men or $55 \%$ of the sample and 10 women or $45 \%$ of the sample). 


\subsection{Data collection}

The interviews, which lasted approximately 90 to 120 minutes, were conducted in person at the official premises of the interviewees. The purpose and objectives of the study were explained to all participants to clarify the final details and potential uncertainties pertaining to their assignments. All participants gave informed consent and were assured anonymity and confidentiality of the information obtained.

The role of the participating experts within the proposed interview process was twofold. First, they had to participate in the analysis of the policymaking process and of the aspects of its success or failure in Slovenia. This part was used in a preliminary paper focusing on the quantitative analysis of the outlined objectives (Mencinger et al., 2017). Second, drawing on their own experience and knowledge of the administrative-political system, they had to provide their vision of the role and significance of strategic and normative factors in public policy design and implementation in Slovenia. The second part was used as the basis for this paper and the conducted qualitative analysis.

The interviews consisted of seven sections of in-depth questions. The first section contained general information and explored which instruments for designing public policies were typically used in public administration in Slovenia. The remaining sections of questions were used for the complex analysis of strategic and normative factors and their impact on the decision-making process in the shaping of PPPPs in Slovenia. The questions in the interviews included several different formats, namely: close-ended questions with numerical estimates and open-ended questions ${ }^{1}$. The responses of the interviewees were voice-recorded, the answers were later converted into transcripts and data tables, and finally the transcripts were documented and archived. The data collected enabled the execution of quantitative analysis presented in the preliminary study (Mencinger et al., 2017) as well as qualitative analysis presented in this paper.

\subsection{Data analysis}

After an extensive review of literature and primary and secondary sources containing problem-related content, the empirical part of the research was carried out. In this manner, the preliminary quantitative empirical analysis (Mencinger et al., 2017) was extensively upgraded with new qualitative approaches. The analysis of the data obtained and the interpretation thereof were carried out using qualitative analysis software, i.e. Atlas.ti, which is frequently used in academia, especially for social science research (Atlas.ti, 2021). The implementation of content analysis using Atlas.ti is based on codifying the key concepts of each dimension explored within the textual transcripts. To increase the objectivity and credibility of the findings obtained, a final

1 The questionnaire is available at http://atena-kronos.si/sl/2018/12/05/vabimo-vas-k-sodelovanjupri-raziskavi/. 
content analysis of the interview transcripts was carried out independently by several coders (authors), whereas all identified inconsistencies were re-evaluated by the coders in a collaborative manner.

\section{Results}

The preliminary study (Mencinger et al., 2017) explored the key factors of public policy decision-making in Slovenia and evaluated their importance in shaping PPPPs on a scale from 0 - not important at all, to 4 - very important/crucial. The interviewees ranked the six interrelated factors in terms of their average importance in the following order: strategic (average 3.4), normative (average 3.25), organizational/human resources/ICT support (average 3.0), economic/financial (average 2.9), institutional (average 2.81), methodological/procedural (average 2.8). The main task discussed in the previously mentioned study was to determine which factors had a significant impact on the decision-making process in the shaping of PPPPs in Slovenian public administration. Hence, according to the results obtained from the 22 top-ranked experts participating in the study, strategic and normative factors were identified as the most crucial factors in shaping PPPPs (Mencinger et al., 2017). In this qualitative analysis, we have built to some extent on data from the preliminary quantitative study, while focusing exclusively on strategic and normative factors. A qualitative analysis was performed and four claims were developed. Based on these criteria, the impact of strategic vs. normative factors was determined. To test the hypothesis outlined in the literature review (stating that 'public policymaking in Slovenia is mainly based on following rules rather than on appropriate strategies') four claims were formulated and tested, namely:

$-\mathrm{C}_{1}$ : The European Union contributes to the design, execution and assessment of PPPPs;

$-\mathrm{C}_{2}$ : Action planning and execution of PPPPs transfers from politics to bureaucracy, when formal strategy does not exist;

$-\mathrm{C}_{3}$ : Public policies are mainly implemented through changes in regulation rather than adopted strategies;

- C4: The level of involvement of the professional and general public in the process of preparation of strategic documents is low.

All four claims were tested with contradictory claims, but none proved to be confirmed. Each network, more precisely its central node, corresponds to a tested claim. The central node is then connected to neighboring nodes (called 'codes' in Atlas.ti). Each code summarizes a group of substantially similar quotations from the interviews. The importance of each code is evaluated by the number of supporting quotations. The verifications of all four claims are shown in Figures $1\left(\mathrm{C}_{1}\right), 2\left(\mathrm{C}_{2}\right), 3\left(\mathrm{C}_{3}\right)$, and $4\left(\mathrm{C}_{4}\right)$.

The network representation in Figure 1 indicates five main grounds (codes) that support claim 1: 'The European Union contributes to the design, execution and as- 


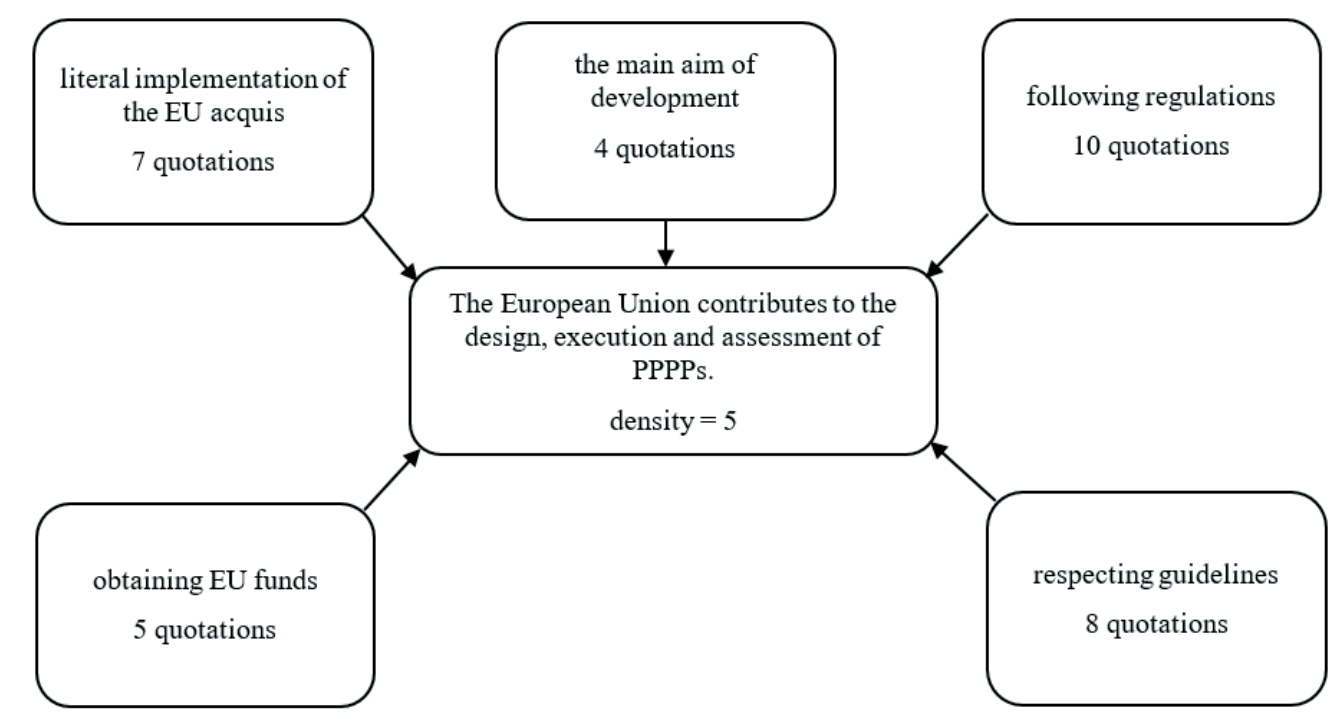

Figure $1\left(\mathbf{C}_{1}\right)$ : 'The European Union contributes to the design, execution and assessment of PPPPs'

Source: The authors

sessment of PPPPs'. Moreover, Figure 1 points out that 'following regulations' and 'respecting guidelines' have the strongest impact. Namely, the codes 'following regulations' and 'respecting guidelines' have most corresponding quotations (supported by ten and eight quotations). For illustration, we selected two direct quotations from the interviews: 'EU policies are the main directions of development and we primarily follow the regulations. Adopting legislation at the EU level imposes a high degree of unification of different policies'. The second quotation mentions that 'in the field of labor, family, and social affairs, the EU rules are fully implemented in practice'. The code 'literal implementation of the EU acquis' is supported by seven quotations. For example, one of the interviewees stated: 'in general, when adopting EU directives, we are quite literally sticking to the implementation of rules in our system and overlooking possible exceptions. The problem is the lack of national long-term planning'. This claim is also supported by the following codes: 'in the adoption process, we often forget to see a broader picture and related implications and we are usually not able to enforce national specifics', or: 'the problem is the overly consistent transposition of EU directives into the national legal framework'.

The PPPPs are either a part of the implementation of the EU regulations or a part of the EU or international development policies. EU regulations are therefore one of the key instruments in planning, executing, and evaluating public policies. In this respect, results demonstrate that EU actors play a very important role in the design, execution and evaluation process in Slovenia. However, processes are, in most cases, focused primarily on direct transposition of the EU acquis into the national legal framework, without much consideration of the strategic national goals. Hence, we can confirm that due to the impact of European Union on the design, execution and 
assessment of public policies, public policymaking in Slovenia is mainly based on following rules rather than on appropriate strategies.

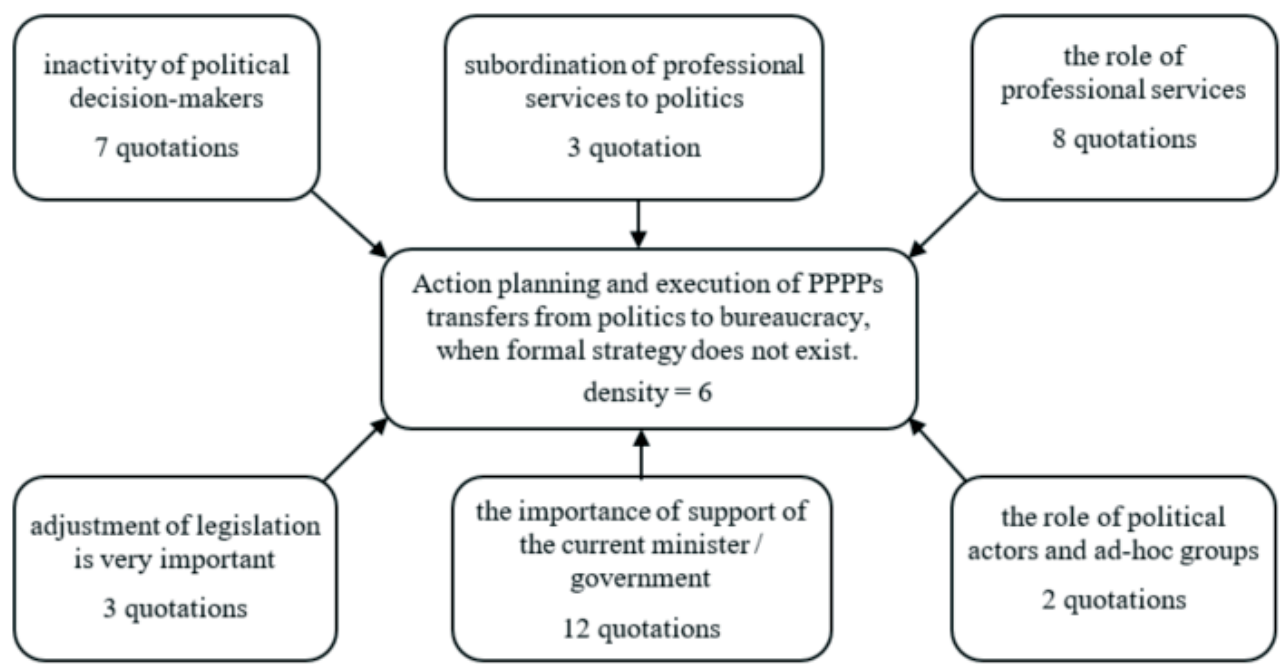

Figure $2\left(\mathbf{C}_{2}\right)$ : 'Action planning and execution of PPPPs transfers from politics to bureaucracy, when formal strategy does not exist'

Source: The authors

Figure 2 identifies six situations where action planning and execution of PPPPs transfers from politics to bureaucracy, when formal strategy does not exist. Although such decision-making can be controversial in many respects, it often gets support from the current minister (or even the whole government). Based on the interviews, this situation is the most common (highest number of supporting quotations, i.e. 12). One of the interviewees illustrated: 'the directorate's professional services prepare a document and the minister adopts it, based on their recommendations. Although the minister is the one who says yes or no, the role of professional services could be decisive in these specific situations and conditions'. Such professional services often substitute for inactive political decision-makers. The codes 'inactivity of political decision-makers' and 'the role of professional services' (indicated in seven and eight quotations, respectively) also confirm this claim. For instance, explicit quotations from the interviews state: 'sometimes the ministers fail to do their job or the guidelines from the government are not clear. In this case, the competent professional services take the highest responsibility'. And: 'due to the absence of a strategy, professional services very often prepare solutions which the minister approves, but it should be the other way around. The weakness of coalition treaties and the absence of strategic planning is evident in these situations'.

These views and opinions illustrate the important role of public administration (bureaucracy) in the process of policymaking. Although public administration should 
be politically independent in policy implementation, strong connections, interdependences, and even conflicts still exist. $\mathrm{C}_{2}$ demonstrates that public administration in Slovenia frequently takes over from the political level a significant share of activities concerning the preparation and execution of PPPPs. In doing so, it relies typically on the existing legal framework and rarely on strategy, as the latter is often not considered or does not even exist. In this respect, we could confirm the hypothesis that advocates the prevalence of legal over strategic framework in PPPPs design and implementation.

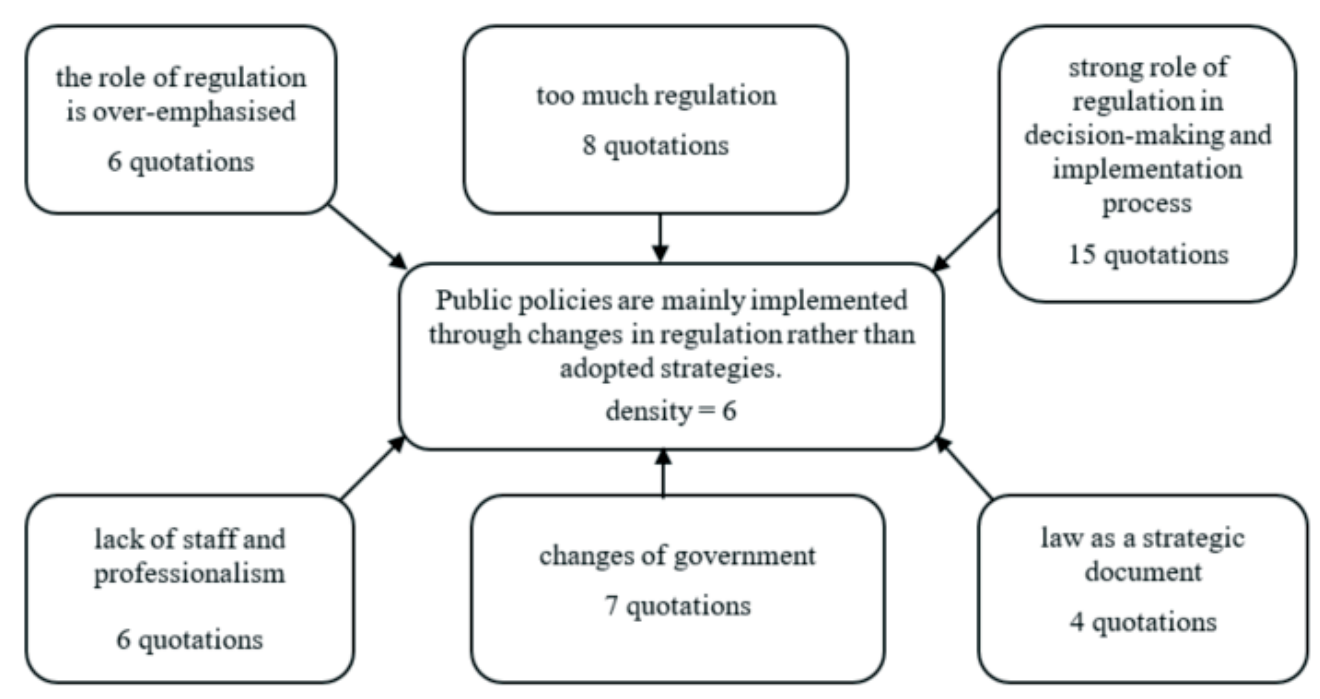

Figure $\mathbf{3}\left(\mathbf{C}_{3}\right)$ : 'Public policies are mainly implemented through changes in regulation rather than adopted strategies'

Source: The authors

Figure 3 displays the perception and argumentations of the interviewees concerning the claim that public policies are mainly implemented through changes in regulation rather than adopted strategies. There are six codes supporting this claim. The code supported by most quotations (15) is 'strong role of regulation in decision-making and implementation process', which clearly indicates the dominant role of regulation over the role of strategy in PPPPs in Slovenia. Illustrative examples of such quotations are: 'decision-making and especially implementation of PPPPs is based primarily on the alignment of sectoral legislation rather than strategy based'. And: 'strategy has no real connection with the legal framework that defines the implementation activities'. Codes like 'role of regulation is over-emphasized' or 'too much regulation' suggest that Slovenia is saturated with regulations and over-formalized in most sectors, e.g. health, education, construction, taxation, environment. The code 'lack of staff and professionalism' also speaks in favor of $\mathrm{C}_{3}$. For example, one of the interviewees indicated: 'Slovenia implements an extremely large amount of normative acts. However, we do not have suitable professional teams to strategically assess 
the documents'. In the last decade, there were four parliamentary elections in Slovenia. The changes of government were therefore frequent, which resulted (according to code 'changes of government') in an unstable environment, change of focus, and backlog of work. This code is supported by seven quotations, for instance: 'we had several organizational restructurations due to change of government in the last five, six years'. Another problem when government changes is reflected in quotations such as: 'change in government announces a change in tax legislation (the impact of politics on the structure of the institution itself)' and 'with each new government, a new strategy is actually being launched'.

The findings of our qualitative analysis are in accordance with the results of the preliminary quantitative analysis concerning these issues (Mencinger et al., 2017). Namely, $70 \%$ of the interviewees report that changes of government - especially from the left to the right-wing or vice versa - have a significant impact on the implementation of PPPPs in Slovenia. This percentage would probably be even higher if all policies followed a strategic plan. Two of the interviewees realistically described the situation: 'we have no strategy, therefore the change of government has no influence'. And: 'a change in government is immediately followed by changes in legislation'. These quotations speak in favor of the hypothesis and emphasize the urgent need to adopt sectoral strategies. In view of that, claim $\mathrm{C}_{3}$ clearly supports the hypothesis that public policymaking in Slovenia is mainly based on following rules rather than on appropriate strategies.

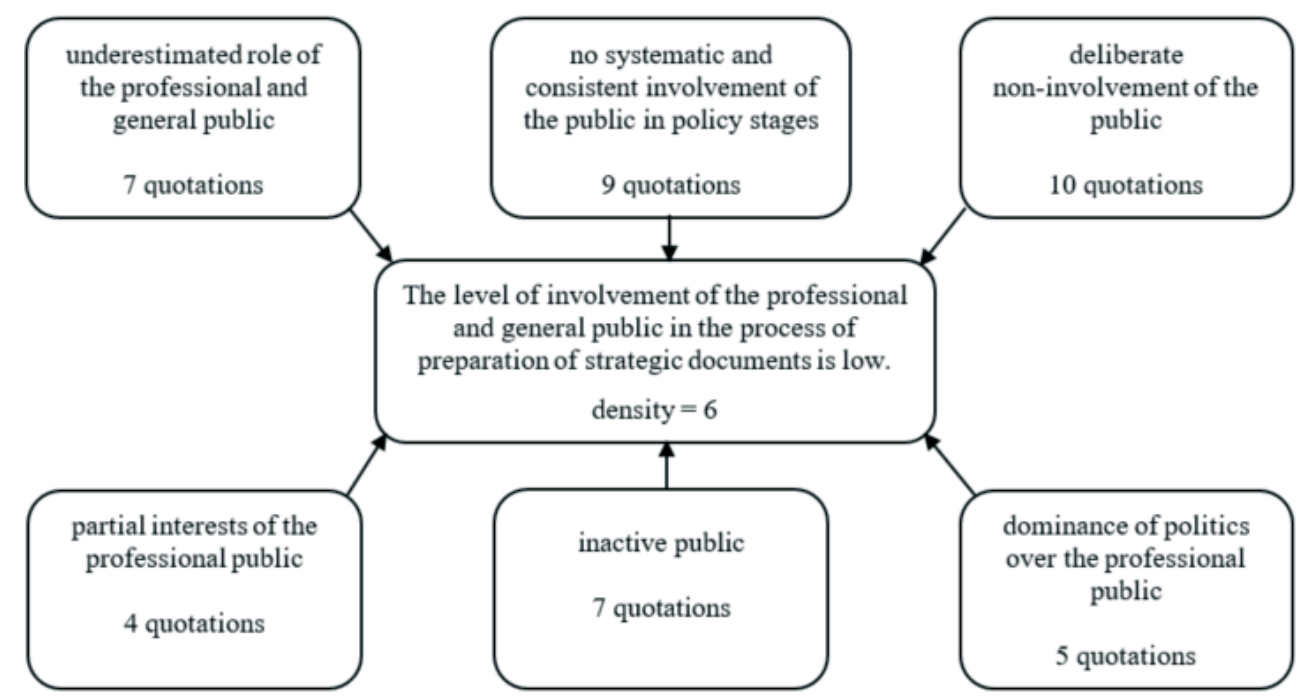

Figure $4\left(\mathbf{C}_{4}\right)$ : 'The level of involvement of the professional and general public in the process of preparation of strategic documents is low'

Source: The authors 
Figure 4 demonstrates that the level of involvement of the professional and general public in the process of preparation of strategic documents is low. There are six codes supporting this claim. The strongest reason is the impact of 'deliberate non-involvement of the public' (supported by 10 quotations) and 'no systematic and consistent involvement of the public in policy stages' (supported by 9 quotations). This clearly indicates that professional and general public is calculatedly not included in the process. Illustrative examples of such quotations (for the first code) are: 'the public is intentionally not invited to participate in the preparation of strategic or other plans' or 'the point is that the public should be involved in strategic planning and co-decisions in public affairs from the very beginning. But this is not the case'. For illustration (for the second code), quotations from the interview state: 'there is no involvement of the professional and general public in the various stages of the policy cycle' and 'if academic experts propose strategic solutions, they are neither systematically nor consistently addressed, regardless of the policy stage'.

Additional reasons might be related to the 'underestimated role of the professional and general public' and 'inactive public' (each supported by 7 quotations). For illustration, we provide two quotations related to the underestimated role of the public: 'consultation with the public is not sincere. This is not an actual partnership or working relationship, it is a pro-forma consultation', and 'the role of the public is underestimated and the public is being consciously manipulated when it comes to strategic matters', and one example for 'inactive public': 'inactive public is merely a reflection of the poor performance of the government'.

The 'dominance of politics over the professional public' shows strong influence of politics, which asserts its interest at the expense of repressed expert opinions. It is supported by seven quotations, for instance: 'political objectives are very often not in line with those of the professional public. The opinion of the public is therefore often ignored'. These views and opinions illustrate an unjustified supremacy of the politics in the process of policy-making when preparing strategic documents. Moreover, although the professional public should be somewhat independent from politics, the analysis shows a moderate influence of 'partial interests of the professional public' (supported by four quotations). In this light, one of the interviewees' statements is particularly concerning: 'the least consideration is given to the needs of the people, partial professional interests often prevail'.

\section{Discussion}

Considering the outlined research hypothesis, we can firmly establish that there are several different factors leading to the fact that public policies are rather designed and implemented by adopting legislation instead of following a strategic framework. This implies that, if no comprehensive long-term national strategy exists (see in detail particularly subsections on verification of claims 2, 3 and 4, which support the hypothesis), it is irrelevant how many copious and effective resources the country 
has. If the main strategic goals are not set and clearly defined, it is, in theory, not possible to implement all public policy cycle stages and, consequently, improve the quality of PPPPs (Keping, 2018). This demonstrates that effective public policymaking on the national level is not possible without a balanced and well-thought-out strategic framework (Novak and Lajh, 2018). These results show that even though strategic factors were identified by the interviewees as the most critical of all factors (Mencinger et al., 2017), normative factors have an unprecedented role due to the deeper socio-political national context. For various reasons and on different levels, normative factors have proven to be crucial in public policymaking in Slovenia. Overall, research findings suggest that only a system-supported mechanism including a balanced combination and application of strategic, normative, methodological/procedural, institutional, economic/financial, and organizational/HR/ICT factors may lead to a sufficient realization of PPPPs.

The European Union has an important steering policy function and offers Member States political, legal and strategic support in terms of consulting, legal documentation and development materials (EC, 2015). The EU legislation may serve as a strategic basis as long as it is satisfactorily flexible and allows countries, regardless of the size, to apply their own national specifics when designing the rules for different policies (Pollitt and Bouckaert, 2011). Thus, reliable normative and procedural frameworks of rule-making ought to be the first stage in building upon strategic public policymaking processes and sound governance in small countries such as Slovenia. Simultaneously, Slovenia must establish and actively develop its integral national development strategy and sector strategies. In the case of Slovenia, empirical findings demonstrate that EU players have a substantial impact on the country's design, execution and assessment of PPPPs. Due to the weak strategic framework, Slovenia has rather neglected the aspect of design and implementation of the respected policies (Vintar, Aristovnik and Klun, 2018). This means that pressure from different $\mathrm{EU}$ institutions (in various forms) tends to replace national strategies to some extent (Boyne and Walker, 2004). EU Member States are bound to comply with the acquis communautaire because EU legislation prevails over national law, especially when EU policies steer the national ministries. Thus, it is possible to anticipate a much more comprehensive and effective design and implementation of policies and the eventual outcomes. However, EU policies are generally proposed by the large EU countries (Lehne, 2012), which can potentially lead to noncompliance with the national priorities and objectives of smaller EU countries. In addition, well-intentioned, positive impacts of EU policy players may present a significant problem, because EU strategic documents do not reflect the strategic long-term goals of Slovenia, which is seen in the insufficient enforcement of national needs in the European and international documents. Lack of public funds, lack of (appropriately trained) personnel, mismatch of strategic objectives at the highest political level, political instability and other reasons have led to a situation where Slovenia mostly just blindly follows EU recommendations and requirements, rather than giving self-initiative proposals (MJU, 2015). 
Slovenia and similar small-sized countries have relatively weak economic and political power, are burdened with the communist past, and have great difficulties in asserting their own interests (Kovač and Bileišis, 2017). With rapid changes of government in Slovenia, the frequency of policy changes is relatively high and there is no comprehensive overview of the past actions, current state, and clear future goals (Makarovič et al., 2016). The lack of general focus, clear top-down goals, consistent and persistent coordination and cooperation at the highest strategic level of government, competences, financial, HR, and other relevant resources further complicate the realization of national needs (Aristovnik et al., 2016; Vintar, Aristovnik and Klun, 2018). By frequent changes in power, the transfer of power from a political to an administrative level is a very common phenomenon, which has adverse effects on the design and implementation of PPPPs.

The Slovene public administration reforms were conceived rather legalistically and that led to an overdetermined legal framework (Stanojević and Mrčela, 2016; Vintar et al., 2013). Interviewees stated that over-reliance on the legal framework rather than on strategy is due to the absence of a specialized unit known as 'policy unit'. This is assumed to be one of the greatest deficiencies in most public organizations accountable for the formulation and implementation of PPPPs. The significance and role of the policy unit ought to be primarily concerned with monitoring, formulation and implementation of PPPPs, and long-term strategic public policy planning (Mencinger et al., 2017). Due to the non-existence of such units, decision-making is left to ad-hoc groups (Timofejevs Henriksson, 2015) and improvisations that are subject to the interests and needs of the current government coalitions, which prefer their political objectives over national ones. This process is often accompanied by inactive and often ignored general public, partial interests of the professional public, and misuse of political power over expert strategic proposals (Novak and Fink-Hafner, 2019). The lack of involvement of the professional and general public in the process of preparation of strategic documents is based on the inertia of the past decades and is, among other things, a direct consequence of the socio-political culture originating from the former political system (Adam, Kristan and Tomšič, 2009). The professional and general public often start to deal with the topics when it is already too late or deal with marginal aspects of public policies, while there is no professional or political debate on the more important issues addressed by these public policies. Thus, we get a seemingly inclusive and functional public policymaking process, which offers many opportunities for the assertion of partial professional or other interests of stronger social groups and the abuse of political power (Zajc, 2010). In these cases, it is much easier for administration to resort to simple and strict compliance with the legal framework than to focus efforts on complex strategic issues that require a lot of resources, coordination, political skills, and a commitment to common goals. It is evident that some balance between legalism and managerialism should be found through participative governance and inclusion of civil society (Vintar et al., 2013). 
The consequences of such shortcomings are public dissatisfaction, incomplete and temporary public policy solutions, deficiently shaped and targeted policies and consequently unsatisfactory outcomes thereof, search for public policy shortcuts (which are often incorrect), public policy without clear arguments and national consensus, and excessive reliance on the legal framework in the formulation and implementation of public policies (Adam, Kristan and Tomšič, 2009; Zajc, 2010).

High importance of normative factors in Slovenia and, consequently, the existence of hyper-regulated normative environment are the outcomes of current and past governments that have mainly focused on the preparation of new legislation rather than long term strategic planning and measures (Kovač and Bileišis, 2017; Stanimirović and Vintar, 2014). High frequency of legislative changes de facto disables comprehensive and regular monitoring and evaluations of expected outputs and outcomes.

The evidence presented here provides a useful insight into the background of policymaking processes in Slovenia and implies that the country is somehow trapped in a vicious circle of past political arrangements, current socio-political culture, and the malfunctioning of the state apparatus in public policymaking. Surpassing these problems will require bold and visionary steps from the next governments, and, above all, active and constructive public involvement in all public policy issues. The selected claims $\left(\mathrm{C}_{1}, \mathrm{C}_{2}, \mathrm{C}_{3}\right.$, and $\left.\mathrm{C}_{4}\right)$ in this respect undoubtedly confirm the basic hypothesis through the opinions, statements and assertions of the interviewees.

\section{Conclusion}

The presented study provides some initial empirical evidence of the role and significance of strategic and normative factors within the public policy making cycle. Research findings confirm that normative factors in practice prevail over strategic factors in public policymaking in Slovenia. This research demonstrates that PPPPs have a greater chance of being designed and implemented if they are rationally and consistently based on the complete public policy making cycle. The results display that the European Union contributes significantly to the preparation of legally binding national documents in Slovenia that provide the basic framework for the design and implementation of PPPPs. National legislation in Slovenia is largely a replication of the EU guidelines and recommendations, which can be a very arguable position for a sovereign state. This in fact implies that Slovenia insufficiently enforces its national specifics within the EU and international documents, without considering national long-term policy strategic objectives. This is reflected also in the existence of a hyper-regulated normative environment in Slovenia. In addition, results demonstrate that when formal strategy does not exist, action planning and execution of PPPPs shifts from politics to bureaucracy. Due to inactive political decision-makers, the bureaucracy often takes over the burden of public policy design and implementation and hence runs the whole public policy process. In the course of action, bureaucracy relies almost entirely on the legal framework without much consideration of strategic 
goals and long-term implications. From this point of view, it is necessary to stress the importance of collaboration and search for consensus between administrative and political leadership on the national level to properly design and implement PPPPs.

Considering the general and methodological limitations of the presented study, some issues need to be pointed out. Since our key claims used for the verification of the outlined hypothesis were rather arbitrarily selected and pre-determined in a theory-based manner, the results and conclusions derived from the interviews can be interpreted and argued to some extent in different ways. We verified the relevance of the key factors through interviews, which did not allow us to consider all potential restrictions, i.e., the conditions that occur in the real environment. Another limitation is related to the representation of the results. When striving to represent empirical findings in a clear and reasonable way, we faced certain methodological dilemmas. For instance, we grouped quotations from the interviews into 'codes', where each code corresponded to a set of substantially similar and analogous quotations. Determining the similarities and analogies between two quotations as well as the naming of the codes may have been, however, subjectively biased. Our decisions were based on the intention to represent the expressed opinions of the interviewees and to derive research results in the most transparent and understandable manner possible.

We believe that further research should focus primarily on deepening the knowledge and understanding of public policy making. This includes identification and analysis of the key factors in the real environment and their verification in actual situations concerning the process of design and implementation of public policies. The analysis identified a few interesting starting points for future research work and investigation. Firstly, how to develop effective and practical strategic planning mechanisms, which could assist the national government in conducting efficient public policy design and implementation. Secondly, how to consolidate and simplify the normative framework and ensure the development and adoption of better quality, functional and flexible legislation. Thirdly, the role of strategic and normative factors in the process of administrative modernization and innovation should be further scrutinized.

To conclude, evidence suggests the establishment of specialized sectoral policy units, adequate procedures and cross-sectoral mechanisms, which could ensure consistent, inclusive, and evidence-based execution of public policy making cycles in Slovenia. This initiative should encompass methodical and painstaking strategic and regulatory impact assessments (ex-ante and ex-post) with the involvement of field experts and the general public. The ultimate goal is to introduce an effective, well-structured, and evidence-based public policymaking cycle and to equip political decision-makers with the appropriate instruments and knowledge, which could ensure the design and implementation of effective PPPPs focused on overall socio-political progress, economic growth, and general development of all national sub-systems. 


\section{References:}

1. Adam, F., Kristan, P. and Tomšič, M., 'Varieties of Capitalism in Eastern Europe (with Special Emphasis on Estonia and Slovenia)', 2009, Communist and Post-communist Studies, vol. 42, no. 1, pp. 65-81.

2. Aristovnik, A., Kovač, P., Stare, J. and Todorovski, P., Slovenska Javna Uprava Na Razpotju Strateških Sprememb (Slovenian Public Administration at the Crossroads of Strategic Changes), Ljubljana: Fakulteta za upravo, 2016.

3. Atlas.ti, 'What is ATLAS.ti?', 2021, [Online] available at https://atlasti.com/product/whatis-atlas-ti/, accessed on February 5, 2021.

4. Baumgartner, F.R. and Jones, B.D., Agendas and Instability in American Politics, Chicago: University of Chicago Press, 2010.

5. Bennett, C.J. and Howlett, M., 'The Lessons of Learning: Reconciling Theories of Policy Learning and Policy Change', 1992, Policy Sciences, vol. 25, no. 3, pp. 275-294.

6. Boyne, G.A. and Walker, R.M., 'Strategy Content and Public Service Organizations', 2004, fournal of Public Administration Research and Theory, vol. 14, no. 2, pp. 231-252.

7. Cohen, M.D., March, J.G. and Olsen, J.P., 'A Garbage Can Model of Organizational Choice', 1972, Administrative Science Quarterly, vol. 17, no. 1, pp. 1-25.

8. Council of Europe, 'Strategy for Innovation and Good Governance at Local Level', 2018, [Online] available at https://www.osce.org/eea/86380?download=true, accessed on July 8, 2021.

9. Demirkaya, Y., 'Strategic Planning in the Turkish Public Sector', 2015, Transylvanian Review of Administrative Sciences, Special Issue, pp. 15-29.

10. Deželan, T., Maksuti, A. and Ursic, M., 'Capacity of Local Development Planning in Slovenia: Strengths and Weaknesses of Local Sustainable Development Strategies', 2014, Lex Localis, vol. 12, no. 3, pp. 547-573.

11. Downs, A., An Economic Theory of Democracy, New York: Harper \& Row, 1957.

12. EC, 'Communication from the Commission to the European Parliament, the Council, the European Economic and Social Committee and the Committee of Regions. Better Regulation for Better Results - An EU Agenda', 2015, [Online] available at https://eur-lex. europa.eu/legal-content/EN/TXT/PDF/?uri=CELEX:52015DC0215\&from=EN, accessed on December 12, 2020.

13. Etzioni, A., 'Mixed-scanning: A “Third" Approach to Decision-making', 1967, Public Administration Review, vol. 27, no. 54, pp. 385-392.

14. Hill, C.W. and Jones, G.R., Essentials of Strategic Management, Boston: Nelson Education, 2011.

15. Hintea, C., 'Strategic Planning in the Public Sector Case Study: Strategic Planning in Cluj-Napoca, Romania', 2008, Transylvanian Review of Administrative Sciences, no. 22E, pp. 51-63.

16. IFAC, 'Enterprise Governance. Getting the Balance Right', 2004, [Online] available at http://www.ifac.org/system/files/downloads/Enterprise_Governance.pdf, accessed on August 8, 2021.

17. Johnsen, A., 'Strategic Management Thinking and Practice in the Public Sector: A Strategic Planning for All Seasons?', 2015, Financial Accountability and Management, vol. 31, no. 3, pp. 243-268. 
18. Johnsen, Å., 'Strategic Planning and Management in Local Government in Norway: Status after Three Decades', 2016, Scandinavian Political Studies, vol. 39, no. 4, pp. 333-365.

19. Johnston, M., 'Good Governance: Rule of Law, Transparency, and Accountability', [Online] available at http://unpan1.un.org/intradoc/groups/public/documents/un/unpan010193.pdf, accessed on June 8, 2021.

20. Keping, Y., 'Governance and Good Governance: A New Framework for Political Analysis', 2018, Fudan Journal of the Humanities and Social Sciences, vol. 11, no. 1, pp. 1-8.

21. Kotnik, Ž. and Kovač, P., 'Development of Public Administration and Governance in Central and Eastern Europe: Content Analysis of The NISPAcee Journal', 2018, NISPAcee Journal of Public Administration \& Policy, vol. 11, no. 1, pp. 229-252.

22. Kotnik, Ž., Umek, L., Kovač, P., Stanimirovic, D. and Vintar, M., 'Analysis of the Key Factors for Successful Public Policy Implementation: A Qualitative Study in Slovenia', 2020, DANUBE: Law, Economics and Social Issues Review, vol. 11, no. 2, pp. 113-140.

23. Kovač, P. and Bileišis, M. (eds.), 'Public Administration Reforms in the Eastern European Union Member States. Post-Accession Convergence and Divergences’, 2017, [Online] available at https://www.dlib.si/stream/URN:NBN:SI:DOC-GOZLT0QL/dc9c67f3-b6ef-4dd b-8f03-28ef0dd1deb2/PDF, accessed on December 20, 2020.

24. Lehne, S., The Big Three in EU Foreign Policy, 2012, Washington, D.C.: Carnegie Endowment for International Peace, 2012.

25. Lindblom, C.E., 'The Science of 'Muddling through", 1959, Public Administration Review, vol. 19, no. 2, pp. 79-88.

26. Makarovič, M., Prijon, L., Rek, M. and Tomšič, M., 'The Strength of Pro-European Consensus among Slovenian Political Elites', 2016, Historical Social Research/Historische Sozialforschung, vol. 41, no. 4, pp. 195-213.

27. Mencinger, J., Kovač, P., Jukić, T. and Vintar, M., 'Public Policy Design and Implementation in Slovenia', 2017, International Public Administration Review, vol. 15, no. 3-4, pp. 9-38.

28. MJU, 'Javna uprava 2020. Strategija razvoja javne uprave 2015-2020' (Public Administration 2020. Public Administration Development Strategy 2015-2020), 2015, [Online] available at http://www.mju.gov.si/fileadmin/mju.gov.si/pageuploads/JAVNA_UPRAVA/Kako vost/Strategija_razvoja_SLO_final_web.pdf, accessed on December 8, 2020.

29. Novak, M. and Fink-Hafner, D., 'Slovenia: Interest Group Developments in a Postsocialistliberal Democracy’, 2019, Journal of Public Affairs, vol. 19, no. 2, e1867, pp. 1-13.

30. Novak, M. and Lajh, D., 'The Participation of Slovenian Civil Society Organisations in EU Policymaking: Explaining Their Different Routes', 2018, fournal of Contemporary European Research, vol. 14, no. 2, pp. 105-122.

31. OECD, Participatory Development and Good Governance, Paris: OECD, 1995.

32. Ongaro, E. and van Thiel, S. (eds.), The Palgrave Handbook of Public Administration and Management in Europe, London: Palgrave Macmillan, 2018.

33. Pollitt, C. and Bouckaert, G., Public Management Reform: A Comparative Analysis - New Public Management, Governance, and the Neo-Weberian State, New York: Oxford University Press, 2011.

34. Sabatier, P.A., 'An Advocacy Coalition Framework of Policy Change and the Role of Policy-oriented Learning Therein', 1988, Policy Sciences, vol. 21, no. 2, pp. 129-168.

35. Simon, H.A., Models of Man: Social and Rational. Mathematical Essays on Rational Human Behavior in a Social Setting, New York: Wiley, 1957. 
36. Stanimirović, D. and Vintar. M., 'Development of eHealth at a National Level - Comparative Aspects and Mapping of General Success Factors', 2014, Informatics for Health and Social Care, vol. 39, no. 2, pp. 140-160.

37. Stanojević, M. and Mrčela, A.K., 'Social Dialogue during the Economic Crisis: The Impact of Industrial Relations Reforms on Collective Bargaining in the Manufacturing Sector in Slovenia', in Koukiadaki, A., Tavora, I. and Lucio, M.M. (eds.), Joint Regulation and Labour Market Policy in Europe during the Crisis, ETUI, 2016, pp. 441-497.

38. Timofejevs Henriksson, P., 'Europeanization of Foreign-aid Policy in Central and East Europe: The Role of EU, External Incentives and Identification in Foreign-aid Policy Adoption in Latvia and Slovenia 1998-2010', 2015, Journal of European Integration, vol. 37, no. 4, pp. 433-449.

39. UN, 'What Is Good Governance?', 2021, [Online] available at https://www.unescap.org/ sites/default/files/good-governance.pdf, accessed on January 8, 2021.

40. Vintar, M., Aristovnik, A. and Klun, M. (eds.), Vidiki in Dejavniki Uspešnega Izvajanja Javnih Politik (Aspects and Factors of Public Policies Implementation), Ljubljana: Faculty of Administration, 2018.

41. Vintar, M., Rosenbaum, A., Jenei, G. and Drechsler, W. (eds.), The Past, Present and the Future of Public Administration in Central and Eastern Europe, Bratislava: NISPAcee Press, 2013.

42. Volkery, A. and Ribeiro, T., 'Scenario Planning in Public Policy: Understanding Use, Impacts and the Role of Institutional Context Factors', 2009, Technological Forecasting and Social Change, vol. 76, no. 9, pp. 1198-1207.

43. Weiss, T.G., 'Governance, Good Governance and Global Governance: Conceptual and Actual Challenges', 2000, Third World Quarterly, vol. 21, no. 5, pp. 795-814.

44. Yin, R.K., Case Study Research and Applications: Design and Methods, Los Angeles: Sage, 2017.

45. Zajc, D., 'Political Science in Slovenia: Driving Democratisation', in Eisfeld, R. and Pal, L.A. (eds.), Political Science in Central-East Europe, Opladen/Farmington Hills: Barbara Budrich, 2010, pp. 281-289. 